\title{
Excavation of a Bronze Age wicker container, Gearraidh na h'Aibhne, Isle of Lewis
}

\author{
by Paul R J Duffy*
}

with contributions from Christopher Burgess and Mark Holmes, Jennifer Miller and Susan Ramsay

Illustrations by Gillian McSwan, John Arthur and Northamptonshire Archaeology

*GUARD, Gregory Building, Lilybank Gardens, University of Glasgow, Glasgow G12 8QQ

Scottish Archaeological Internet Report 19, 2006 www.sair.org.uk 
Published by the Society of Antiquaries of Scotland, www.socantscot.org.uk with Historic Scotland, www.historic-scotland.gov.uk

Editor Debra Barrie

Produced by Archetype Information Technology Ltd, www.archetype-it.com

ISBN: 0903903881

ISSN: $1473-3803$

Requests for permission to reproduce material from a $S A I R$ report should be sent to the Director of the Society of Antiquaries of Scotland, as well as to the author, illustrator, photographer or other copyright holder.

Copyright in any of the Scottish Archaeological Internet Reports series rests with the SAIR Consortium and the individual authors.

The maps are reproduced from Ordnance Survey material with the permission of Ordnance Survey on behalf of The Controller of Her Majesty's Stationery Office. (CCrown copyright 2001. Any unauthorized reproduction infringes Crown copyright and may lead to prosecution or civil proceedings. Historic Scotland Licence No GD 03032G, 2002.

The consent does not extend to copying for general distribution, advertising or promotional purposes, the creation of new collective works or resale. 


\section{Contents}

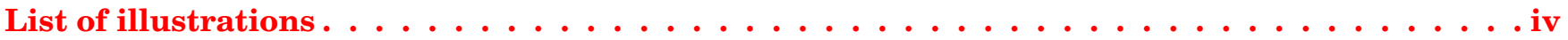

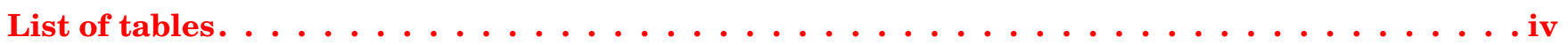

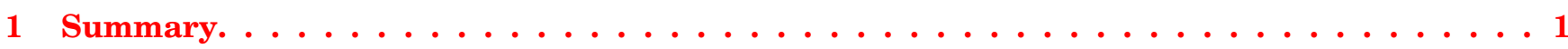

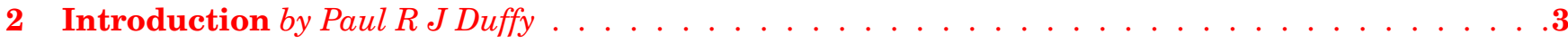

3 The Excavation by Christopher Burgess and Mark Holmes . . . . . . . . . . . . . . . . . . . .4

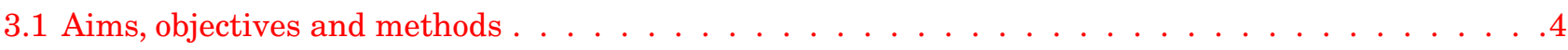

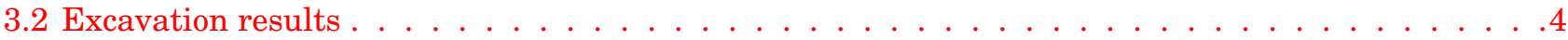

4 Botanical Remains by Jennifer Miller and Susan Ramsay . . . . . . . . . . . . . . . . . . . 7

4.1 Wood fragments . . . . . . . . . . . . . . . . . . . . . . . .

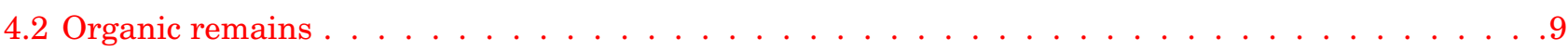

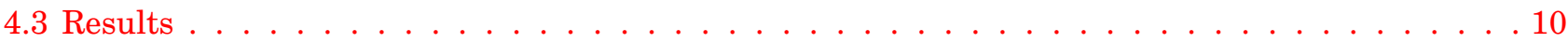

5 Radiocarbon Dates from Gearraidh na h'Aibhne by Paul $R$ J Duffy . . . . . . . . . . . . . . . . 11

6 Discussion by Paul $R$ J Duffy, with Jennifer Miller \& Susan Ramsay . . . . . . . . . . . . . . . . 12

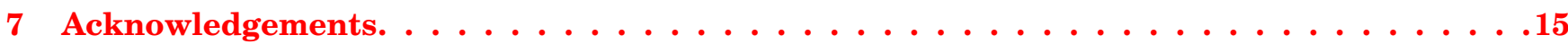

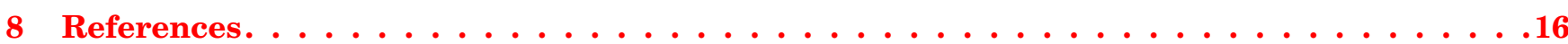




\section{List of illustrations}

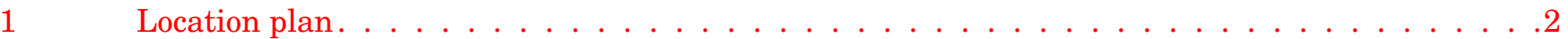

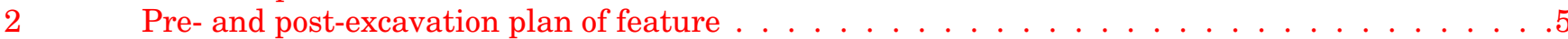

3 Sections of feature . . . . . . . . . . . . . . . . . . . . . 6

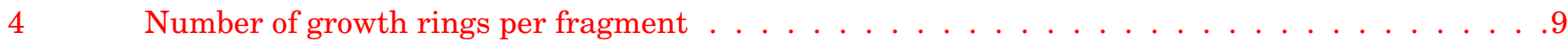

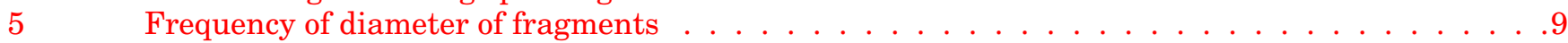

\section{List of tables}

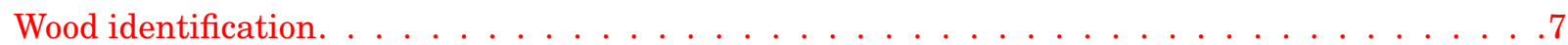

Radiocarbon dates . . . . . . . . . . . . . . . . . . . ....11 


\section{Summary}

An archaeological excavation was carried out at Gearraidh na h'Aibhne near Calanais on the Isle of Lewis (illus 1) by Northamptonshire Archaeology, working for Glasgow University Archaeological Research Division (GUARD) as part of the Historic Scotland Human Remains Call Off Contract. The site, initially interpreted as a cist potentially containing a bog body, was identified during annual peat cutting. Excavation demonstrated that the feature was in fact an oval pit containing a quantity of hazel branches, capped with a number of flat slabs of Lewisian Gneiss. Several similar stones had been placed in the base of the feature, overlying more hazel branches.

The observation of several branches placed vertically at the edges of the cut suggests that the wood remains may have originally constituted a wicker structure or basket. Further evidence of anthropogenic activity was identified in the form of bent and/or twisted hazel rods and cut marks on a larger piece of wood. Growth-ring analysis of the hazel pieces identified two distinct age clusters: a large group of pieces between five and seven years old and a smaller group between ten and 13 years old, indicating the hazel branches had been deliberately selected for size. Analysis of preserved botanical macrofossil remains indicated that heather type stems and Sphagnum moss might have been incorporated or deposited into the structure. Two radiocarbon dates of 1080x830 BC (SUERC-2086) and 1000x830 BC (SUERC-2087) at 2-sigma probability were obtained from two discrete samples of hazel, suggesting the structure was constructed and deposited during the Late Bronze Age. 

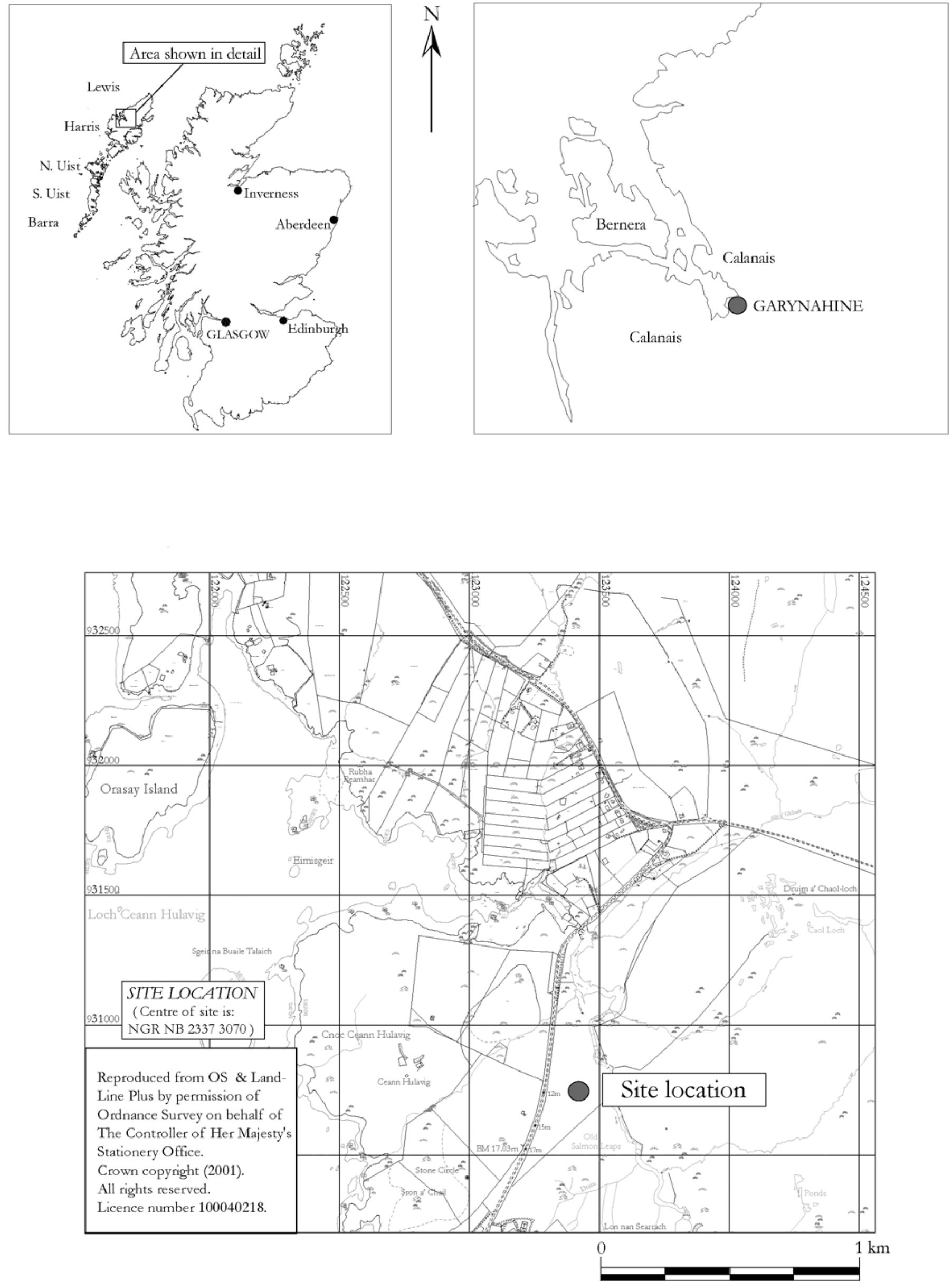

Illus 1 Location plan 


\section{Introduction by Paul $R$ J Duffy}

The site was initially discovered by $\mathrm{Mr}$ Donald Angus Mackay, when a number of flat stone slabs were uncovered at a depth of $1.5 \mathrm{~m}$ during annual peat cutting. The discovery was promptly reported to Dr Mary MacLeod, Regional Archaeologist, who concluded that the form and morphology of the remains was suggestive of a cist, potentially containing a bog body. Based on this interpretation, Glasgow University Archaeological Research Division (GUARD) were commissioned by Historic Scotland to undertake an archaeological excavation under the provisions of the Human Remains Call Off Contract. With the agreement of Historic Scotland, a team from Northamptonshire Archaeology who were in the area were commissioned to undertake the fieldwork according to a written scheme of investigations prepared by GUARD. The work was undertaken in June 2002.

The site of Gearraidh na h'Aibhne (NGR: NB 2333 3068 ) is located on flat ground, $10 \mathrm{~m}$ above Ordnance Datum, on the upper river terrace of the west bank of the Abhainn Dhubh (Black River). The excavation area is located $200 \mathrm{~m}$ west of the river, $80 \mathrm{~m}$ from the main road (B8011). The remains were at a depth of just over $1.5 \mathrm{~m}$ in a south-facing peat cutting. The area is currently used for grazing, peat cutting and sporting activities. It is covered with blanket peat and has a typical acid moorland vegetation profile of coarse grasses, mosses and heather. The peat is currently undergoing cutting. Local geology is mapped as glacial till overlying Lewisian Gniess.

The specialist reports below are edited versions of the full texts, which form part of the site archive. The site archive has been sent to the National Monuments Record of Scotland, RCAHMS, Edinburgh. No conservation was undertaken on the wood, following an assessment by AOC Ltd Edinburgh, and it is currently being assessed by the Treasure Trove Advisory Committee. It is anticipated that a hyperlink to this document detailing final archive location will be inserted following a decision on the disposal of the material. 


\section{The Excavation by Christopher Burgess and Mark Holmes}

\subsection{Aims, objectives and methods}

The primary objectives of the excavation were to establish whether human remains were present within the cist, the degree of preservation of such remains and how such remains had been deposited. The secondary objectives were to establish whether there were any intimately related structures in the vicinity of the site, and to record fully and recover any human remains and associated structures or, in the event of multiple burials, to consult with Historic Scotland and the Regional Archaeologist to establish a suitable mitigation strategy.

An area $c 3 \mathrm{~m}$ by $2 \mathrm{~m}$ was opened around the exposed stones. After initial cleaning, the trench was half-sectioned and excavation was undertaken in spits, until the cut of a small pit was encountered. The half section was then continued down through the fills of the pit on the south-western side and the section recorded. Once recorded, the remaining fill in the north-eastern half of the feature was excavated. Heavy rain and poor light meant that all of this initial excavation was carried out largely on the basis of texture.

The following day, significantly improved weather and drying of the peat in the excavation area allowed better identification of the archaeological deposits and revealed the feature had initially been incompletely excavated at the base of its north side. The remaining portion of the pit was subsequently excavated by Jim Crawford (Gearraidh na h'Aibhne) and Mark Elliot (Stornoway Museum).

\subsection{Excavation results}

Initially, an upper layer of turf and light brown peat (001), $0.2 \mathrm{~m}$ thick, was removed to reveal a layer of more fibrous light brown peat $0.65 \mathrm{~m}$ thick (002). A deposit of stones, both pitched and laid flat, was exposed at this level (008). The stones varied in size from $0.15 \mathrm{~m}$ by $0.15 \mathrm{~m}$ by $0.10 \mathrm{~m}$ up to $0.5 \mathrm{~m}$ by $0.4 \mathrm{~m}$ by
$0.2 \mathrm{~m}$, with the majority measuring $c 0.35 \mathrm{~m}$ by $0.2 \mathrm{~m}$ by $0.2 \mathrm{~m}$. The larger stones tended to be flat whilst the smaller stones were more rounded. Several of the stones were heavily decayed and there were patches of natural green clay between some (illus 2).

Following half-sectioning of the trench, the cut of the pit was observed in plan (003). The cut was oval in shape and aligned on a north-west/south-east axis. On the surface it was $1 \mathrm{~m}$ long by $0.65 \mathrm{~m}$ wide. It had nearly vertical upper sides and was $0.85 \mathrm{~m}$ deep. In the bottom third of the pit, the sides curved outward very slightly so that its base was marginally larger than its mouth, giving it a bell-shaped profile.

The upper fill (004) of the pit comprised a very moist, light brown peat. It contained abundant fibrous straw-like material. Underlying this was a black peat (005) containing what appeared to be occasional curins (small chunks of dried peat) and frequent small pieces of wood, which occurred most noticeably at its interface with the upper peaty fill (004). Within both the upper peaty fill (004) and the black peat (005), numerous fragments of wood were recovered (illus 3). Most of the wood was not in situ and therefore it was not possible to tell for certain if the vertical members were regularly spaced. From the surviving pieces, however, the impression during excavation was of an interwoven wicker 'basket', held in place by larger stakes, some of which were observed to be vertically embedded in the cut (003).

At the base of the pit was another deposit of black peat (006), similar in character to context 005 but containing frequent curins and occasional wood fragments. This fill sat upon the natural light green, gritty, compact clay. A further layer of stones, initially thought either to be natural boulders or bedrock, were identified during the second day of excavation as in fact lying in the bottom of the pit. Removal of these stones revealed further wood twigs, indicating that the stones probably lay in the bottom of the wickerwork liner. 


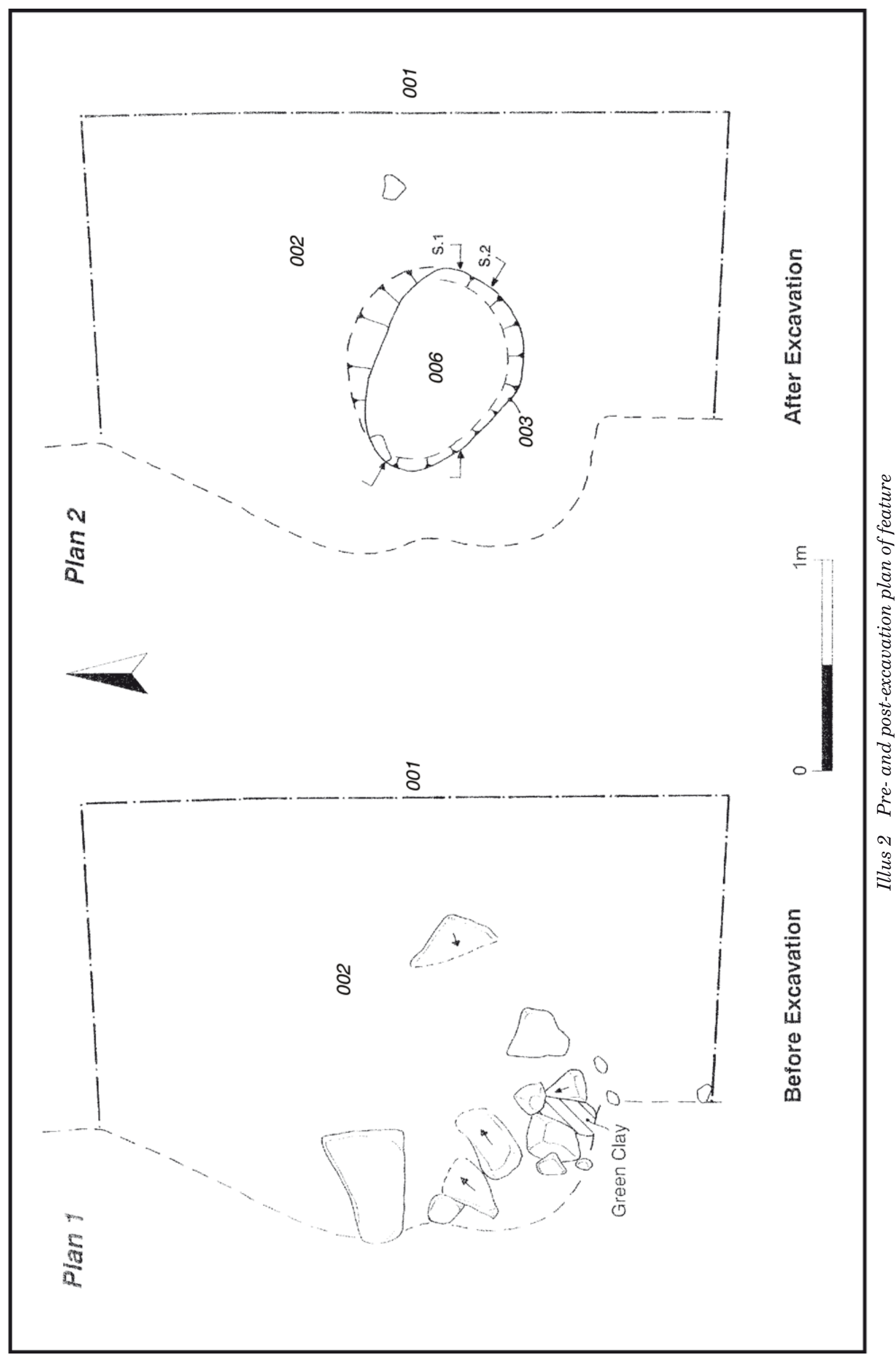




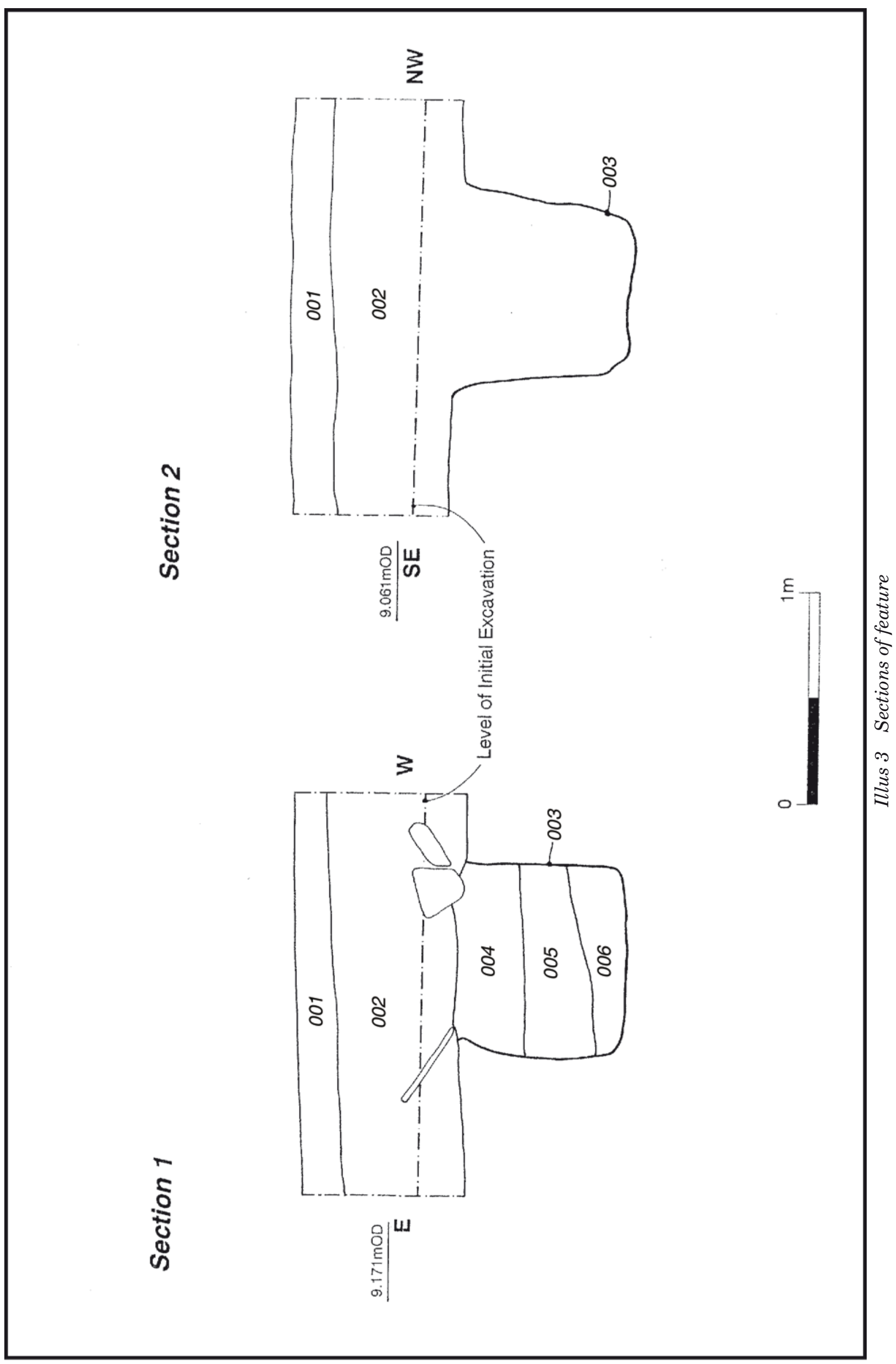




\section{Botanical Remains \\ by Jennifer Miller and Susan Ramsay}

\subsection{Wood fragments}

Six bags of wood were collected during excavation, representing samples from the upper peaty fill (004) and the middle fill of black peat (005). After an initial examination of all pieces, a maximum of 10 fragments of randomly selected wood from each of these bags were retained for closer examination and specific identification in order to get an accurate indication of the taxon assemblage. This number was judged sufficient, as the taxon variation was extremely low. Initial observations regarding length, diameter, and type and degree of any working observed for each fragment were recorded. Subsequently, the numbers of growth rings present were counted by low magnification microscopy at variable magnifications of between $\times 10$ and $\times 40$ using a Ceti binocular microscope and independent cold light source. Subsequent analysis of the internal wood anatomy of each fragment was undertaken on transverse, longitudinal and radial longitudinal wood sections at magnifications of $\times 100$ and $\times 400$, mounted in water on microscope slides. Identification was undertaken with reference to the photographs and descriptions in Anatomy of European Woods (Schweingruber 1990).

A total of 59 fragments of wood were identified (Table 1), of which 58 were hazel (Corylus) and one willow (Salix). All fragments were small roundwood, with none exceeding $25 \mathrm{~mm}$ diameter. Almost all were straight, unbranched pieces, and several still had bark extant. Only two fragments showed evidence of having been bent or twisted, although several had evidence of working, either as a single, oblique cut at one end or split longitudinally. The latter form of working was observed mainly on the larger diameter fragments. One of the largest diameter fragments had numerous cut marks at one end to fashion a rough point.

Illustration 4 shows the number of growth rings and diameter of fragments, each expressed in terms of frequency of occurrence. Illustration 5 shows a cluster of occurrences of fragments with an age range of five to seven years, with another, smaller,

Table 1 Wood identification

\begin{tabular}{|c|c|c|c|c|c|c|c|c|}
\hline Context & Sample & $\begin{array}{l}\text { Bag } \\
\text { no }\end{array}$ & $\begin{array}{c}\text { Fragment } \\
\text { no }\end{array}$ & $\begin{array}{l}\text { Length } \\
(\mathrm{mm})\end{array}$ & $\begin{array}{l}\text { Diameter } \\
\text { (mm) }\end{array}$ & $\begin{array}{l}\text { Growth } \\
\text { rings }\end{array}$ & Taxon & Comments \\
\hline \multirow[t]{9}{*}{ 004/005 } & 004 & - & 1 & 85 & 19 & 5 & Corylus & Roundwood \\
\hline & & & 2 & 100 & 20 & 11 & Corylus & Roundwood \\
\hline & & & 3 & 90 & 20 & 6 & Corylus & Roundwood \\
\hline & & & 4 & 52 & 10 & 8 & Corylus & Roundwood \\
\hline & & & 5 & 75 & 7 & 8 & Corylus & $\begin{array}{l}\text { Roundwood with two small } \\
\text { side branches }\end{array}$ \\
\hline & & & 6 & 55 & 17 & 5 & Corylus & Roundwood \\
\hline & & & 7 & 47 & 14 & 5 & Salix & $\begin{array}{l}\text { Roundwood, split } \\
\text { longitudinally }\end{array}$ \\
\hline & & & 8 & 75 & 5 & 13 & Corylus & Roundwood \\
\hline & & & 9 & 50 & 5 & 5 & Corylus & Roundwood \\
\hline \multirow[t]{10}{*}{005} & 006 & 1 & 1 & 90 & 22 & 6 & Corylus & Roundwood \\
\hline & & & 2 & 100 & 17 & 7 & Corylus & Roundwood \\
\hline & & & 3 & 88 & 12 & 5 & Corylus & Roundwood \\
\hline & & & 4 & 78 & 23 & 6 & Corylus & Roundwood \\
\hline & & & 5 & 65 & 12 & 5 & Corylus & Roundwood \\
\hline & & & 6 & 95 & 23 & 6 & Corylus & Roundwood with bark \\
\hline & & & 7 & 38 & 24 & 6 & Corylus & Roundwood \\
\hline & & & 8 & 47 & 8 & 4 & Corylus & Roundwood \\
\hline & & & 9 & 72 & 10 & 6 & Corylus & Roundwood with bark \\
\hline & & & 10 & 170 & 22 & 7 & Corylus & Roundwood \\
\hline 005 & 006 & 2 & 1 & 100 & 22 & 7 & Corylus & Roundwood with bark \\
\hline
\end{tabular}


Table 1 (cont.) Wood identification

\begin{tabular}{|c|c|c|c|c|c|c|c|c|}
\hline Context & Sample & $\begin{array}{l}\text { Bag } \\
\text { no }\end{array}$ & $\begin{array}{l}\text { Fragment } \\
\text { no }\end{array}$ & $\begin{array}{l}\text { Length } \\
(\mathbf{m m})\end{array}$ & $\underset{(\mathbf{m m})}{\operatorname{Diameter}}$ & $\begin{array}{l}\text { Growth } \\
\text { rings }\end{array}$ & Taxon & Comments \\
\hline & & & 2 & 110 & 11 & 7 & Corylus & Roundwood \\
\hline & & & 3 & 185 & 20 & 7 & Corylus & Roundwood with bark \\
\hline & & & 4 & 125 & 13 & 12 & Corylus & Roundwood \\
\hline & & & 5 & 88 & 11 & 13 & Corylus & Roundwood with bark \\
\hline & & & 6 & 115 & 11 & 6 & Corylus & Roundwood with bark \\
\hline & & & 7 & 87 & 12 & 5 & Corylus & Roundwood with bark \\
\hline & & & 8 & 92 & 20 & 7 & Corylus & Roundwood \\
\hline & & & 9 & 65 & 17 & 6 & Corylus & Roundwood \\
\hline & & & 10 & 100 & 17 & 10 & Corylus & Roundwood, forked branch \\
\hline \multirow[t]{10}{*}{005} & 006 & 3 & 1 & 145 & 10 & 13 & Corylus & Roundwood \\
\hline & & & 2 & 130 & 10 & 10 & Corylus & Roundwood with bark \\
\hline & & & 3 & 85 & 14 & 6 & Corylus & Roundwood \\
\hline & & & 4 & 120 & 9 & 7 & Corylus & Roundwood \\
\hline & & & 5 & 75 & 13 & 6 & Corylus & Roundwood with bark \\
\hline & & & 6 & 90 & 13 & 6 & Corylus & Roundwood \\
\hline & & & 7 & 80 & 20 & 20 & Corylus & $\begin{array}{l}\text { Roundwood, split } \\
\text { longitudinally }\end{array}$ \\
\hline & & & 8 & 40 & 20 & 16 & Corylus & $\begin{array}{l}\text { Roundwood, split } \\
\text { longitudinally }\end{array}$ \\
\hline & & & 9 & 100 & 22 & 15 & Corylus & $\begin{array}{l}\text { Roundwood, split } \\
\text { longitudinally }\end{array}$ \\
\hline & & & 10 & 130 & 30 & 15 & Corylus & $\begin{array}{l}\text { Roundwood, many side } \\
\text { branches removed but healed }\end{array}$ \\
\hline \multirow[t]{10}{*}{005} & 006 & 4 & 1 & 80 & 12 & 6 & Corylus & Roundwood \\
\hline & & & 2 & 152 & 11 & 5 & Corylus & Roundwood \\
\hline & & & 3 & 80 & 20 & 12 & Corylus & $\begin{array}{l}\text { Roundwood, split } \\
\text { longitudinally }\end{array}$ \\
\hline & & & 4 & 50 & 24 & 15 & Corylus & Roundwood \\
\hline & & & 5 & 95 & 9 & 5 & Corylus & Roundwood \\
\hline & & & 6 & 60 & 20 & 7 & Corylus & Roundwood \\
\hline & & & 7 & 82 & 22 & 13 & Corylus & Roundwood \\
\hline & & & 8 & 155 & 13 & 6 & Corylus & Roundwood, slightly twisted \\
\hline & & & 9 & 50 & 23 & 10 & Corylus & Roundwood \\
\hline & & & 10 & 110 & 10 & 7 & Corylus & $\begin{array}{l}\text { Roundwood, twisted into } \\
\text { U-shape }\end{array}$ \\
\hline \multirow[t]{10}{*}{005} & 006 & 5 & 1 & 40 & 18 & 6 & Corylus & Roundwood \\
\hline & & & 2 & 45 & 15 & 6 & Corylus & Roundwood \\
\hline & & & 3 & 95 & 18 & 8 & Corylus & Roundwood \\
\hline & & & 4 & 145 & 15 & 4 & Corylus & $\begin{array}{l}\text { Roundwood, single oblique 'cut' } \\
\text { at one end }\end{array}$ \\
\hline & & & 5 & 240 & 15 & 10 & Corylus & Roundwood with bark \\
\hline & & & 6 & 260 & 20 & 5 & Corylus & $\begin{array}{l}\text { Roundwood with bark, single } \\
\text { oblique 'cut' at one end }\end{array}$ \\
\hline & & & 7 & 205 & 13 & 6 & Corylus & $\begin{array}{l}\text { Roundwood, single oblique 'cut' } \\
\text { at one end }\end{array}$ \\
\hline & & & 8 & 200 & 20 & 8 & Corylus & $\begin{array}{l}\text { Roundwood, possible worked } \\
\text { point but badly eroded }\end{array}$ \\
\hline & & & 9 & 245 & 9 & 3 & Corylus & Roundwood with bark \\
\hline & & & 10 & 245 & 24 & 12 & Corylus & $\begin{array}{l}\text { Roundwood, numerous cut } \\
\text { marks which shape one end to } \\
\text { a rough point }\end{array}$ \\
\hline
\end{tabular}




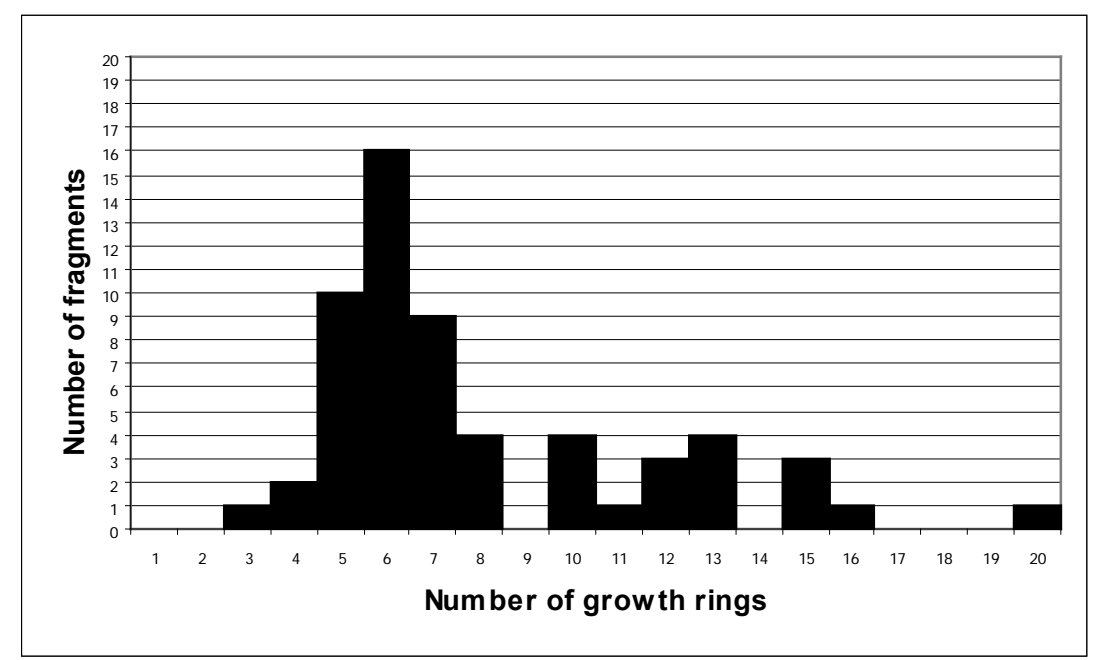

Illus 4 Number of growth rings per fragment

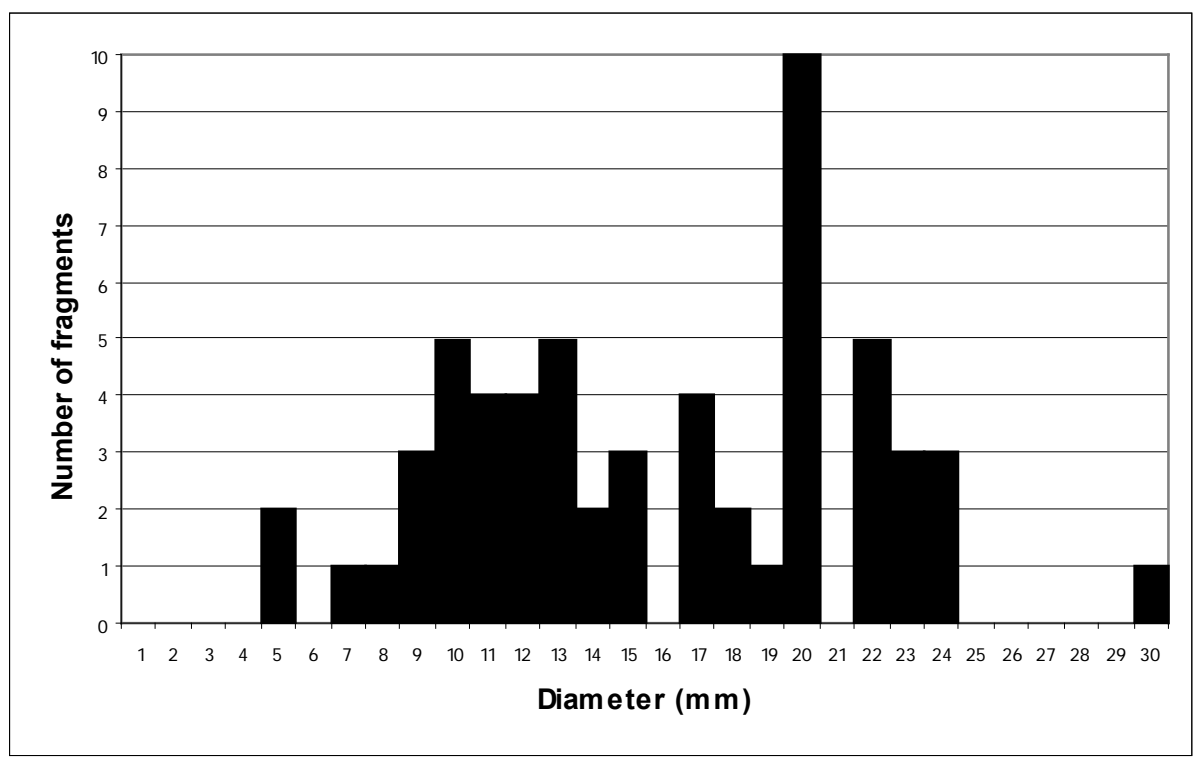

Illus 5 Frequency of diameter of fragments

cluster at ten to 13 years. A similar clustering of fragment diameter is seen in illustration 5 , with smaller fragments being around $9-13 \mathrm{~mm}$ wide, and larger ones about $20 \mathrm{~mm}$.

\subsection{Organic remains}

Four bulk samples of organic material from the upper peaty fill (004) and the middle fill of black peat (005) were analysed for macroscopic plant remains. One-litre and 500-ml sub-samples of this material, respectively, were wet-sieved in the laboratory using sieves of mesh diameter $1 \mathrm{~mm}$ and $500 \mu \mathrm{m}$, in order to remove fine organic detritus and facilitate identification of the waterlogged plant macrofossil remains within the matrix. Sorting and preliminary identification were undertaken using low magnification microscopy at variable magnifications of between $\times 4$ and $\times 45$. Specific identification of plant macrofossils was facilitated by reference to Zadenatlas der Nederlandsche Flora (Beijerinck 1947), Atlas of Seeds and Small Fruits of Northwest-European Plant Species with Morphological Descriptions (Berggeren 1969), British Mosses and Liverworts (Watson 1981) and the extensive Glasgow University botanical reference collection. Vascular plant nomenclature follows New Flora of the British Isles (Stace 1997). All seeds and a representative sample of vegetative plant macrofossil remains were recovered, identified and stored in glass vials, preserved in a mixture of glycerine, ethanol and formalin. 


\subsection{Results}

Numerous heather (Calluna vulgaris) and crossleaved heath (Erica tetralix) leafy shoots, flowers and immature capsules were recorded from contexts 004 and 005. However, almost no root material was observed in the samples examined from those contexts. The absence of heather type roots indicates that these heathland plants had not grown in situ. Abundant remains of monocotyledonous (grass and sedge) stem and leaf fragments were recorded from both contexts 004 and 005, as well as numerous sedge nutlets and rhizomes. Given the absence of heather type roots and the creation of a sump effect through the digging of the original pit, it is considered more likely that the soligenous vegetation types (eg sedges and pondweed) are the product of in situ growth, whereas the hummock vegetation (eg heather, cross-leaved heath and Sphagnum papillosum) had been deposited intentionally. 


\section{Radiocarbon Dates from Gearraidh na h'Aibhne by Paul R J Duffy}

Two samples of single entity Corylus roundwood charcoal from the black peaty middle fill of the pit (005) were sent for accelerator dating at the Scottish Universities Research and Reactor Centre (Table 2). One sample was of five-year-old wood, the other of 12-year-old wood. Dates of $2815 \pm 40$ вP (SUERC-2086) and $2780 \pm 35$ вP (SUERC-2087) were obtained at a 2-sigma level of confidence. The dates were calibrated on $\mathrm{OxCal}$ v3.6.

The dated material points to a secure date in the first quarter of the first millennium BC. In broad terms, therefore, we can suggest that the site is likely to date to the Late Bronze Age.

Table 2 Radiocarbon dates

\begin{tabular}{llrrrr}
\hline Lab code & Sample material & Lab age BP & ว C13 & \multicolumn{2}{c}{ Calibrated dates (BC) } \\
\cline { 4 - 5 } & & & 1-sigma & 2-sigma \\
\hline SUERC-2086 (GU-11674) & Corylus roundwood & $2815 \pm 40$ & $-27.4 \%$ & $1005-905$ & $1080-830$ \\
SUERC-2087 (GU-11675) & Corylus roundwood & $2780 \pm 35$ & $-28.0 \%$ & $980-840$ & $1000-830$ \\
\hline
\end{tabular}




\section{Discussion by Paul $R$ J Duffy, with Jennifer Miller \& Susan Ramsay}

The Gearraidh na h'Aibhne excavations and postexcavation analysis have demonstrated that the site comprised a small pit, containing a possible woven hazel wicker lining or basket, created at some point 1000x830 BC, and has posed some enigmatic questions as to the original function of the pit and artefact. At the time the site was created, the landscape of Lewis is thought to have been undergoing increasing modification due to human action. Environmental analysis of a peat core from Little Loch Roag, to the south of Gearraidh na h'Aibhne, suggests that a predominantly treeless landscape dominated by willow scrub and tall herb communities had gradually given way to a wider expansion of pasture, grasslands and heather moor from around $2000 \mathrm{BC}$, possibly as a result of increased grazing (Birks \& Madsen 1979). Although evidence relating to the spread of the blanket peat bogs across the island is more sparse and somewhat inconclusive, paleobotanical remains from the site of Gearraidh na h'Aibhne has demonstrated that the present bog landscape was well established by around $1000 \mathrm{BC}$ in the immediate area. Modern discussions of the local landscape define it as 'extremely oceanic valley mire' (Ratcliffe 1977), marked by the presence of soligenous tracts and soaks containing sedges, rushes, bog pondweed and Sphagnum moss, and dominated in drier parts and hummock areas by Sphagnum papillosum, heather (Calluna vulgaris), crossleaved heath (Erica tetralix) and purple moor-grass (Molinia caerulea). Macrofossil evidence recovered from contexts 004 and 005 of the Gearraidh na h'Aibhne pit demonstrated the presence of both soligenous vegetation (bogweed and sedges) and hummock-forming vegetation (heathers and mosses) and provides us with a picture of a landscape largely similar to that which we see today.

Into this boggy landscape a bell-shaped pit was excavated to a depth of some $0.85 \mathrm{~m}$. The function of the pit is not immediately apparent, but into it a quantity of hazel branches, carefully selected for size and/or age, were placed. Intriguingly, these branches may have originated from deliberately managed woodland, for they are straight and unbranched in form, with the characteristic side shoots of wild hazel notably absent. Although evidence is rare in the prehistoric record, parallels can be found for evidence of prehistoric coppicing practices in both Scotland and Britain. Miller, in a discussion of the paleobotanical evidence from Oakbank Crannog, Loch Tay, proposes evidence for managed woodland from the site (Miller 2002), whilst further afield, similar practices has been suggested from the Iron Age sites of Fengate and Dragaby (Coles et al. 1978) and from the Somerset Levels as far back as the third millennium BC (Rackham 1977; Coles 1987). What is less apparent is a source for this material on prehistoric Lewis. Birks \& Madsen suggest that hazel was never abundant on the island and would have grown only as scrub in small, isolated areas (Birks \& Madsen 1979). Similarly, a survey of 40 sites on Lewis by Wilkins failed to identify any in situ hazel stumps in ancient peat deposits (Wilkins 1984). The results from the Gearraidh na h'Aibhne excavations suggest either that the resource was more available than has previously been suggested, or that a scarce resource was deliberately utilized as part of the wicker construction. An alternative possibility is that the hazel did not originate on the island at all, but was imported either as unworked lengths, or as a completed artefact. Further paleobotanical study on the island may help to understand this issue more fully.

No distinct artefactual form was recorded during the excavation, although from observation the excavators formed the firm impression that the wood constituted in situ portions of a woven wickerwork, either in the form of a basket or wattle lining. Such an impression appears to be supported by the suggestion that the wood has been deliberately coppiced and selected (see Section 4 - Botanical Remains). Several of the wood pieces also show evidence of anthropogenic modifications, either through longitudinal splitting of the wood (8\%) or as a single oblique cut at one end of a branch (7\%). These types of modifications are typical of those found in the manufacture of wattle or baskets, with the former particularly reminiscent of modern basketmaking, with longitudinal splitting of branches used to create either the slathe or skiens and single oblique cuts for creating either a slype for working the weave, or as a final trim of the weavers themselves (Crook 2000). Two further pieces (3\%) also show signs of twisting. Whilst this figure appears low, it is obvious from an examination of modern parallels that large lengths of constituent branches remain largely unaffected in this way by the manufacture process. Given the relatively short length of the majority of the pieces examined, it is entirely possible that this form of modification would not be expected in any frequency in the analysis of a subsample of material. Additionally, the wood itself remains in a fairly plastic state when wet, and given the waterlogged nature of the site, the sample examined may have shed any evidence of having been woven when the container was broken up.

The balance of evidence, albeit somewhat circumstantial, therefore suggests that the hazel rods within the pit potentially represented some form of woven lining or container. Parallels for both 
types of woven construction are not uncommon. From Scotland, evidence for the use of such woven artefacts is found at the mid Bronze Age site of Linshie Gutter (Terry 1995), whilst similar wickerwork has also been identified from Rattray (Murray et al. 1992) and Howe (Dickson \& Dickson 2000, 98). Several examples of deposition of woven containers in a bog context, within a discussion of bog butter containers from Ireland (Earwood 1997) and Scotland (Hunter 1997) are also known. Further afield, well-preserved baskets have been found in excavations at Glastonbury Lake Village (finds x64 and x90) (Bulleid \& St George Grey 1911), whilst a possible wicker cradle is reported from Mere Village (Bulleid \& St George Grey 1948). Other examples of such wicker and hurdle work have been found throughout Britain and Ireland (for example Coles et al. 1978, 17; O'Sullivan 1998), and a clear picture emerges from these examples of a continuum of construction methods utilizing hazel wickerwork in Britain dating back to the earliest times.

The majority of the diameters of the examined fragments from Gearraidh na h'Aibhne range between $9 \mathrm{~mm}$ and $20 \mathrm{~mm}$. In this light, it is hard to envisage a light construction, and it is probable that the wickerwork was sturdily built, although in the absence of quantified botanical data it is difficult to assess the dimensions of the weave of the basket. Excavated examples from Glastonbury Lake village do, however, give some idea of scale. Here the branches utilized in the construction of basket x64 ranged from $9 \mathrm{~mm}$ to $12.5 \mathrm{~mm}$, allowing a construction estimated to be some $700 \mathrm{~mm}$ in width and $480 \mathrm{~mm}$ in height. Artefact x90 was constructed of similar sized branches and was estimated to be some $330 \mathrm{~mm}$ in width and $480 \mathrm{~mm}$ in height (Bulleid \& St George Grey 1911). Such evidence suggests that the woven object from Gearraidh na h'Aibhne could have been of substantial size in its original unbroken form, and certainly large enough to substantially fill the $650 \mathrm{~mm}$ wide by $850 \mathrm{~mm}$ deep pit.

Other than this, we have little evidence to suggest the original form of the artefact, as the remains of the wicker artefact were, for the most part, not in situ and had been disturbed and broken. The processes by which the artefact had become broken are unknown, and lack of archaeological evidence renders any suggestions as to the causes of the breakage entirely speculative, beyond the suggestion of natural taphanomic processes or deliberate human activity. This action must, however, have taken place prior to the formation of the later peat layer (002), and may have resulted in the pitched and disturbed nature of the overlying stones (008). The only additional evidence as to the form of the artefact comes from the observation that it had been held in place within the pit. A single example of hazel was identified that had been fashioned into a rough point at one end through numerous cut marks, and of several vertically embedded pieces of hazel were observed in the sides of the cut. The presence of a number of stones at the base of the feature, underlain by further hazel twigs, may also be seen as a further measure to maintain the position of the structure within the pit.

In terms of functionality, it is clear that the site was created to contain something, but the nature of the contents remains elusive. In its final visible form the pit was apparently capped with a number of flat slabs of Lewisian Gneiss placed at the surface from where the pit was cut, which later subsided into the top of the feature. As such, it is tempting to see the slabs as deliberate markers for the pit, suggesting the contents were intended to be retrieved at a later date. Evidence from the excavation was not, however, definitive and the alternative possibility that the slabs are later than the pit, possibly added to cover the 'soft spot' in the surface, must be acknowledged. Furthermore, as the disturbed and broken nature of the hazel rods found sealed within the pit suggests that material within had been largely removed, few clues were left as to the original contents. The presence of rootless examples of common heather, cross-leaved heath and Sphagnum moss is considered to have been an intentional deposition but, given the presumed abundance of such plants, it seems somewhat unlikely that the pit would have been dug specifically for their storage. Both plants have a long association with Scottish basketry and may have been used as additional weavers either for decoration or as reinforcement of the structure, or alternatively as some form of packing or cushion for now decayed contents.

Although the morphological characteristics of the wattle-lined 'firebaskets' from Rathtinaun (Crannog 61; O'Sullivan 1998, 89) and the remains from Gearraidh na h'Abbhne do not bear close comparison, such sites remind us of the varied possibilities of function. If we are to consider the plant material within the pit to be part of the structure, however, then perhaps the most obvious possibility is as a storage place for the water from the bog itself. Parallels can be seen in the later examples of such structures, most strikingly from the Iron Age site of Dragonby, where a hazel wattle-lined well was found associated with domestic structures (May 1970), although the motivations for storage of water within a wet bog are somewhat more obscure. In this light, the mosses and heathers contained within may be a rough 'filtration' system to exclude organic material from the surrounding bog. If packing was the function of these plants, however, closer parallels for the site can be drawn from the numerous 'bog butter' depositions from Britain and Ireland. Finds of this fatty, pungent material have been recorded from pits cut into the wet peatlands of the British Isles since antiquarian times, and it is frequently found in containers, including wicker baskets (Earwood 1997). Recent work has suggested that the material can be composed of both animal fats and lipids (Berstan et al. 2004), although the reason for the deposition of the material in bogs is still a source of debate. Such sites generally have a provenance from the mid-Iron Age onwards, but their 
origins and the motives for deposition are poorly understood. Hunter, in a review of such sites from Scotland, suggests a possible votive explanation for such deposits, linked to agricultural fertility (Hunter 1997). More significantly, it is apparent from the associated gazetteer that examples of associations between bog butter, wooden or wicker containers and wetland environments have previously been identified, and are predominantly distributed in the north-west of Scotland. Whilst no direct evidence of the 'butter' was found from the site of Gearraidh na h'Abbhne, it is clear that the contents of the pit have been disturbed, most obviously during the retrieval of the contents, and the 'clay' or waxy substance identified in the uppermost layer of the pit perhaps hints enigmatically at the last vestiges of these, or similar, organic contents.

In summary, the fragmented and partial nature of the wooden remains from the pit frustratingly only hint at the possible form and function of the site. The excavator observations, evidence for coppicing practices, anthropogenic modification of the branches and parallels from several sites in the region and further afield do, however, suggest that some form of wickerwork was buried in the peat bogs of Gearraidh na h'Abbhne, in the late Bronze Age. Tentative hints of bog butter deposition, the proximity of the site to the Calanais stones, and its location within the wider Calanais landscape may entice further discussion of the site in a socio-religious or votive context. In time, further excavated parallels may also help to elucidate more fully the function of the site. More immediately, the site serves to remind us of the archaeological potential contained within the blanket bogs of Lewis, and indeed Scotland, and the potential of such sites to enhance our knowledge of past human practice through the study of the organic material preserved within. 


\section{Acknowledgements}

The fieldwork was undertaken with the assistance of Ed Taylor. Thanks also to thank Jim Crawford (Tigh Mealros and Gearraidh na h'Abbhne), Mark Elliot (Stornoway Museum) and Donald Angus Mackie (landowner). Thanks also to Patrick Ashmore, Gavin MacGregor and Jennifer Miller for thoughts and comments on the final publication text. The project was monitored by Patrick Ashmore for Historic Scotland, who specified and funded the project. It was managed for GUARD by Gavin MacGregor and Jennifer Miller. 


\section{References}

Beijerinck, W 1947 Zadenatlas der Nederlandsche Flora. Veenman \& Zonen, Wageningen.

Berggren, G 1969 Atlas of Seeds and Small Fruits of Northwest-European Plant Species with Morphological Descriptions. Part 2, Cyperaceae. Stockholm.

Berstan, R, Dudd, S N, Copley M S, Morgan, E D, Quye, A \& Evershed, R P 2004 'Characterisation of bog butter using a combination of molecular and isotopic techniques', Analyst 129 (3), 270-5.

Birks, H J B \& Madsen, B J 1979 'Flandrian vegetational history of Little Loch Roag, Isle of Lewis, Scotland', J Ecology 67, 825-42.

Bulleid,A \& St George Gray, H 1911 The Glastonbury Lake Village: a Full Description of the Excavations and the Relics Discovered, 1892-1907. Glastonbury Antiquarian Society, Glastonbury.

Bulleid, A \& St George Gray, H 1948 The Meare Lake Village: a Full Description of the Excavations and the Relics from the Eastern Half of the West Village, 1910-33. Somerset Archaeological Society, Taunton Castle.

Coles, B J 1987 'Trackways across the wetlands: multi-disciplinary studies in the Somerset levels of England', in Coles, J M \& Lawson, A J (eds) European Wetlands in Prehistory. Clarindon Press, Oxford.

Coles, J M, Heal, S V E \& Orme, B J 1978 'The use and character of wood in prehistoric Britain and Ireland', Proc Prehist Soc 44, 1-45.

Crooke, G 2000 Basketmaking. Crowood Press, Marlborough.

Dickson, C A \& Dickson, J H 2000 Plants and People in Ancient Scotland. Tempus, Stroud.

Earwood , C 1997 'Bog-butter: a two thousand-year history', J Irish Archaeol 8, 25-42.
Hunter, F 1997 'Iron Age hoarding in Scotland and northern England', in Gwilt, A \& Haselgrove, C Reconstructing Iron Age Societies: New Approaches to the British Iron Age, 108-33. Oxbow Books, Oxford.

May, J 1970 'Dragaby', Antiquarian J 50, 222-45.

Miller, J 2002 'Oakbank crannog: building a house of plants', in Ballin-Smith, B \& Banks, I (eds) In the Shadow of the Brochs: the Iron Age in Scotland, 35-44. Tempus, Stroud.

Murray, H K, Murray, J C, Shepard, A N \& Shepard, A G 1992 'Evidence of agricultural activity of the later second millenium BC at Rattray, Aberdeenshire', Proc Soc Antiq Scot 122, 113-25.

O'Sullivan, A 1998 The Archaeology of Lake Settlement in Ireland. Discovery Programme Monograph 4, Dublin.

Rackham, O 1977 'Neolithic woodland management in the Somerset Levels: Garvin's, Walton Heath and Rowland's Tracks', Somerset Levels Papers $3,65-71$.

Ratcliffe, D A 1977 Highland Flora. Highlands and Islands Development Board, Inverness.

Schweingruber, F H 1990 Anatomy of European Woods. Haupt, Berne.

Stace, C 1997 New Flora of the British Isles, 2nd Edn. Cambridge University Press, Cambridge.

Terry, J 1995 'Excavations at Linshie Gutter unenclosed platform settlement, Crawford, Lanarkshire', Proc Soc Antiq Scot 125, 369-427.

Watson, EV 1981 British Mosses and Liverworts, 3rd Edn. Cambridge University Press, Cambridge.

Wilkins, D A 1984 'The Flandrian woods of Lewis (Scotland)', J Ecology 72, 251-8. 